\title{
A Novel Green Synthesis of Thalidomide and Analogs
}

\author{
Ellis Benjamin ${ }^{1}$ and Yousef M. Hijji ${ }^{2}$ \\ ${ }^{1}$ Department of Chemistry, Stockton University, 101 Vera King Farris Drive, Galloway, NJ 08205-9441, USA \\ ${ }^{2}$ Department of Chemistry and Earth Sciences, Qatar University, P.O. Box 2713, Doha, Qatar \\ Correspondence should be addressed to Yousef M. Hijji; yousef.hijji@qu.edu.qa
}

Received 13 November 2016; Accepted 18 January 2017; Published 20 February 2017

Academic Editor: José L. Arias Mediano

Copyright (C) 2017 Ellis Benjamin and Yousef M. Hijji. This is an open access article distributed under the Creative Commons Attribution License, which permits unrestricted use, distribution, and reproduction in any medium, provided the original work is properly cited.

\begin{abstract}
Thalidomide and its derivatives are currently under investigation for their antiangiogenic, immunomodulative, and anticancer properties. Current methods used to synthesize these compounds involve multiple steps and extensive workup procedures. Described herein is an efficient microwave irradiation green synthesis method that allows preparation of thalidomide and its analogs in a one-pot multicomponent synthesis system. The multicomponent synthesis system developed involves an array of cyclic anhydrides, glutamic acid, and ammonium chloride in the presence of catalytic amounts of 4-N,N-dimethylaminopyridine (DMAP) to produce thalidomide and structurally related compounds within minutes in good isolated yields.
\end{abstract}

\section{Introduction}

Thalidomide has a long and tragic past that stems from its teratogenic effects. However, recent studies prove that it is an effective immunomodulatory, antiangiogenic, and anticancer pharmaceutical $[1,2]$. This reemergence of thalidomide has led to a number of FDA approved derivatives including lenalidomide and pomalidomide (multiple myeloma) [3-5]. Currently thalidomide and its derivatives are used in the treatment of numerous diseases including Crohn [6-8], Leprosy [9-11], Graft-Versus-Host (GVHD) [12-14], and multiple forms of cancer [15-17]. They are also known to modulate the expression patterns of several proteins including TNF $\alpha$ [18-22], IL1 $\beta$ [23-27], and COX2 [28-31]. In fact, discovery of lenalidomide and pomalidomide had led scientists to explore the modification of thalidomide (Figure 1) to improve its efficacy and decrease its teratogenic and neurotoxic effects. Although there are several synthetic methods for making thalidomide many of the reported syntheses are often multistep processes which use exotic or expensive reagents, maintain long reaction times, and produce very low yields [32-43].

Our novel microwave assisted synthesis of thalidomide and its derivatives improves over current conventional and microwave assisted syntheses through the high yields of thalidomide and its systematic derivatization within minutes. Microwave application in organic synthesis has seen exponential growth over the last twenty years due to its easy experimental conditions, rapid turnaround, easy workups, and high yields. The speed at which microwave reactions are done matches well with combinational processes to synthesize derivatives for improved biological activity when compared to low-yielding conventional synthesis especially that of thalidomide and its analogs (24\%). The power of microwave synthesis is utilized for speeding the reaction and providing an efficient convenient way of obtaining these thalidomide variations or related compounds [44-46].

Thalidomide and a series of its analogs (2-5) are shown in Figure 2 and synthesized in a one-pot reaction (Scheme 1), using mild conditions and inexpensive reagents, under green (microwave) conditions with relatively high yields. The strategy is based on utilizing the corresponding anhydrides, either commercially available anhydrides or constructed based on our earlier work of microwave assisted Diels Alder reaction of maleic anhydride with the required 1,3-diene. The synthesis of thalidomide (1) and derivatives (2-5) was accomplished in a one-pot reaction of glutamic acid with the corresponding anhydride and ammonium chloride with the use of DMAP as a base catalyst mixture at $150^{\circ} \mathrm{C}$ in 10 minutes. In this reaction we were able to form both substituted and unsubstituted 


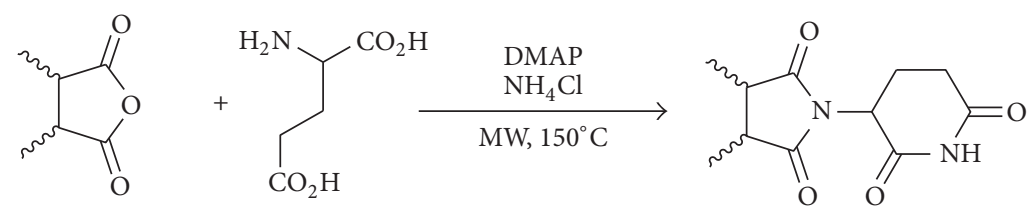

Scheme 1: The synthesis of thalidomide and its analogs. Microwave conditions: 10 minutes at $150^{\circ} \mathrm{C}$.

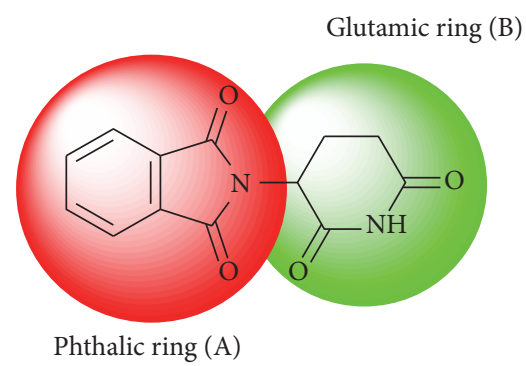

FIgURE 1: The structure of thalidomide.

cyclic imides through two condensation reactions of the cyclic anhydride and the glutamic acid moieties, respectively. The formation of unsubstituted imide is based on the generation of ammonia through the removal of proton from the ammonium chloride. The thalidomide derivatives produced a glutarimide ring with a diversity of cyclic anhydrides bound.

A primary benefit of our synthetic method over previous thalidomide syntheses methods includes the ability to modify the phthalic ring (Figure 1, moiety (A)). Although extensive work has focused on the modification of glutamic ring (Figure 1, moiety (B)) of thalidomide such as introduction of dithiocarbamate in order to enhance its biological activities, the carbon backbone is modified so that it can allow for variation in structure and functionality. This method focuses on the modification of the phthalic ring moiety of thalidomide (Figure 1), allowing for the addition of multiple carbon skeletons including bicyclic systems. Our synthesis allows for the exploration of the effects of ring size, ring strain, increased polarity, and structural complexity in addition to stereochemistry. These compounds may shed light on structure-activity relationship in thalidomide derivatives thereby improving their efficacy. Another benefit of this method is the ability to easily introduce labeled nitrogen through the use of ammonium-15N chloride in the reaction mixture.

Although this process occurs in one pot, it involves a multistep mechanism in which the amine of glutamic acid has to form an amide acid with the cyclic anhydride. If the cyclic amide-glutamic acid is not formed then reaction seems to proceed towards byproduct formation with the cyclic imide as the major product. A study to determine which catalyst could improve ammonia generation and product formation of thalidomide in the microwave<smiles>O=C1CCC(N2C(=O)c3ccccc3C2=O)C(=O)N1</smiles>

$1(86 \%)$<smiles>O=C1CCC(N2C(=O)CCC2=O)C(=O)N1</smiles>

$3(48 \%)$<smiles>O=C1CCC(N2C(=O)[C@H]3CCCC[C@H]3C2=O)C(=O)N1</smiles>

$2(62 \%)$<smiles>O=C1CCC(N2C(=O)[C@H]3CC[C@H]3C2=O)C(=O)N1</smiles>

$4(47 \%)$<smiles>O=C1CCC(N2C(=O)[C@H]3C4C=CC(C4)[C@H]3C2=O)C(=O)N1</smiles>

$5(59 \%)$

Figure 2: Thalidomide and thalidomide analogs synthesized.

was done using thiourea, ammonium acetate, and ammonium chloride/DMAP with phthalic anhydride using similar molar ratios. Previous research in our laboratory has found several ways to produce ammonia from ammonium acetate and hydroxylamine ( $\mathrm{HCl} / \mathrm{DMAP}$ with ammonium acetate being the best $[47,48]$. This study used GC-MS for determining the ratio of unsubstituted cyclic imides (phthalimide) to thalidomide. The data shows that ammonium acetate is highly efficient at forming phthalimide (90\% yield) but not thalidomide (yield $<7 \%$ ). On the other hand, the reaction resulted in higher yields of thalidomide when DMAP/ $/ \mathrm{NH}_{4} \mathrm{Cl}(43 \%)$ and thiourea (40\%) were used, Table 1.

The main byproduct formed when ammonium acetate is used is a cyclic imide and this may be explained by the rapid dissociation of ammonium acetate to give ammonia that initiates quick imide formation. Differences in the reactivity between ammonium acetate and ammonium chloride finds that ammonium chloride is highly stable and does not break down under microwave irradiation. The addition of DMAP as a base catalyst to ammonium chloride causes it to dissociate and generate ammonia at higher temperature, allowing glutamic acid to first react with the anhydrides to 


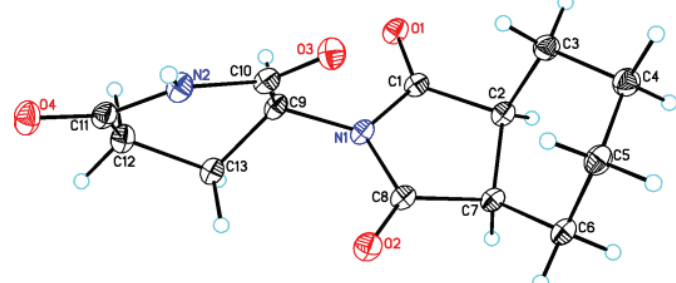

2

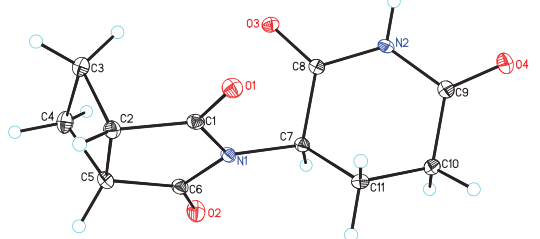

4

FIGURE 3: ORTEP drawings of compounds (3) and (4).<smiles>O=C1CCC(N2C(=O)c3ccccc3C2=O)C(=O)N1</smiles>

Glutamic acid $\mathrm{NH}_{4} \mathrm{Cl}$, DMAP, MW<smiles>O=C1NC(=O)c2ccccc21</smiles>

Exclusive<smiles>O=C1OC(=O)c2ccccc21</smiles><smiles>CC(C)(C)CCCCC(N)=O</smiles><smiles>O=C1NC(=O)c2ccccc21</smiles>

Exclusive

Scheme 2: Synthesis of phthalimide and thalidomide.

TABLE 1: Comparison of thalidomide synthesis using DMAP/ $\mathrm{NH}_{4} \mathrm{Cl}$, $\mathrm{NH}_{4} \mathrm{OAc}$, and thiourea in the monomode microwave at $150^{\circ} \mathrm{C}$ for 10 minutes.

\begin{tabular}{lcc}
\hline Reagent & Phthalimide & Thalidomide \\
\hline Thiourea & $59 \%$ & $40 \%$ \\
DMAP NH$_{4} \mathrm{Cl}$ & $57 \%$ & $43 \%$ \\
Ammonium acetate & $90 \%$ & $7 \%$ \\
\hline
\end{tabular}

form the imide (moiety (A)) followed by the generation of ammonia at higher temperature and the formation of the 2,6-dioxopiperidine, $\mathrm{NH}_{4} \mathrm{Cl}$ ring later (moiety (B)). Long term tests (over 30 minutes) of $\mathrm{NH}_{4} \mathrm{Cl}$ under microwave irradiation found that it does not readily break down and needs the presence of the DMAP as a base catalyst to initiate ammonia production allowing time for cyclic amideglutamic acid formation (Scheme 2).

Compounds (1-5) were generated within minutes, even though the yields are moderate due the competition with ammonia generated in one-pot synthesis system. The yields are acceptable given the ease and simplicity of the reaction system. Compounds (1-5) were isolated, purified, and identified by spectroscopic analysis. (Detailed ${ }^{1} \mathrm{H}$ and ${ }^{13} \mathrm{C}$ NMR spectra and mass spectrometry data are presented in the Supplementary Material available online at https://doi.org/10.1155/2017/6436185.) Further structural confirmation was provided by single crystal X-ray structural identifications [49]. Compounds 3 and 4 ORTEP are presented in Figure 3. Compound 3 presents interesting structural features with 4- and 5-membered fused rings with the piperidinedione ring at almost right angle with the pyrrolidine ring containing dihedral angles of $67.6^{\circ}$ and $73.9^{\circ}$ for the cyclobutane and 2,6-dioxopiperidine rings, respectively. Compound 5 has an intriguing structure that contains a bicyclic system with 4 chiral centers, a double bond that is a handle for further functionalization and a possibility of two more chiral centers.

In conclusion, we have developed a novel green one-pot synthetic technique for the generation of thalidomide and its analogs. Although this article shows only a small subset of compounds, there are a limitless number of derivatives that can be produced/derived using this technique. This technique also has a wide variety of applications as it relates to the production of thalidomide analogs that may be used for the treatment of multiple diseases. 


\section{Appendix}

\section{Experimental}

A CEM Discover monomode microwave was used for microwave enhanced organic synthesis. Isolation procedures use TLC as a basis for the column chromatography of the materials. Gas Chromatography Mass Spectrometry (GCMS) will be used to quantify and identify the amounts of product and possible byproducts found in the purified materials.

Standardized methods for the identification of products consisted of GC-MS, ${ }^{1} \mathrm{H}$ NMR, ${ }^{13} \mathrm{C}$ NMR, DEPTC NMR, melting point, and Infrared Spectroscopy (IR). Every new compound synthesized was completely analyzed by all corresponding techniques. Gas Chromatograph Mass Spectrometry was performed using either a Shimadzu GC17A and GC-MS-QP5050A LabSolutions system or a Varian CP 3800 and Saturn 2200 system.

All IR spectra were performed on a Perkin-Elmer Spectrum RX I IR system. All melting points determinations were performed on a Laboratory Devices Mel-Temp II instrument. ${ }^{1} \mathrm{H},{ }^{13} \mathrm{C}$, and DEPT-C NMR were performed on Bruker $400 \mathrm{MHz}$. All solvents (HPLC grade) were purchased from Fisher Scientific Corporation. All reagents were purchased from Aldrich Chemical Company and were used without purification.

\section{Thalidomide Synthesis}

2-(2,6-Dioxopiperidin-3-yl)isoindole-1,3-dione. (1): phthalic anhydride $(0.10 \mathrm{~g}, 0.68 \mathrm{mmol})$, glutamic acid $(0.10 \mathrm{~g}$, $0.68 \mathrm{mmol})$, DMAP (0.02 g, $0.16 \mathrm{mmol})$, and $\mathrm{NH}_{4} \mathrm{Cl}(0.04 \mathrm{~g}$, $0.75 \mathrm{mmol}$ ) were mixed thoroughly in a CEM-sealed vial with a magnetic stirrer. The sample was heated for $10 \mathrm{~min}$ at $150^{\circ} \mathrm{C}$ in a CEM Discover microwave powered at $150 \mathrm{~W}$. It was then cooled rapidly to $50^{\circ} \mathrm{C}$. When at room temperature it was dissolved in $15 \mathrm{~mL}$ of $(1: 1)$ ethyl acetate : acetone. The organic layer was washed with $2 \mathrm{x}(10 \mathrm{~mL})$ distilled water and then dried over sodium sulfate (anhydrous). The organic layer was concentrated under vacuum. The residue was treated with hexanes $(30 \mathrm{~mL})$ affording a white solid $(0.14 \mathrm{~g}$, $80 \%$ ). mp $268-270^{\circ} \mathrm{C} .{ }^{1} \mathrm{H}$ NMR $\left(400 \mathrm{MHz}, \mathrm{DMSO}-d_{6}\right) \delta$ 11.14 (s, $1 \mathrm{H}, \mathrm{NH}), 7.94$ (m, $4 \mathrm{H}, \mathrm{Ar}), 5.17$ (dd, $1 \mathrm{H}, 12.5,5.5 \mathrm{~Hz})$, $2.92(\mathrm{~m}, 1 \mathrm{H}), 2.57(\mathrm{~m}, 2), 2.09(\mathrm{~m}, 1 \mathrm{H}) ;{ }^{13} \mathrm{C}$ NMR $(100 \mathrm{MHz}$, DMSO- $\left.d_{6}\right)$ 172.7, 169.8, 167.1, 134.9, 131.2,123.4, 49.0, 30.9, 22.0; MS $m / z 258(\mathrm{M}+)$; 230, 213, 202, 173, 148, 111, 76, 50 .

2-(2,6-Dioxopiperidin-3-yl)-hexahydro-isoindole-1,3-dione. (2): a white solid (70\% yield). ${ }^{1} \mathrm{H}$ NMR $(400 \mathrm{MHz}, \mathrm{DMSO}-$ $\left.d_{6}\right) \delta 11.0(\mathrm{~s}, 1 \mathrm{H}, \mathrm{NH}), 4.9(\mathrm{dd}, 1 \mathrm{H}, 12.5,5.5 \mathrm{~Hz}), 3.0(\mathrm{~m}$, $1 \mathrm{H}), 2.8$ (m, 2 H), $2.5(\mathrm{~m}, 1 \mathrm{H}), 1.9(\mathrm{~m}, 1 \mathrm{H}), 1.7(\mathrm{~m}, 3 \mathrm{H}), 1.6$ $(\mathrm{m}, 1 \mathrm{H}), 1.4(\mathrm{~m}, 4 \mathrm{H}) ;{ }^{13} \mathrm{C}$ NMR $\left(100 \mathrm{MHz}, \mathrm{DMSO}-d_{6}\right) 178.8$ $(\mathrm{C}=\mathrm{O}), 178.7(\mathrm{C}=\mathrm{O}), 172.7(\mathrm{C}=\mathrm{O}), 169.4(\mathrm{C}=\mathrm{O}), 48.7(\mathrm{CH})$, $39.1(\mathrm{CH}), 38.8(\mathrm{CH}), 30.7\left(\mathrm{CH}_{2}\right), 23.1\left(\mathrm{CH}_{2}\right), 22.9\left(\mathrm{CH}_{2}\right)$, $21.1\left(\mathrm{CH}_{2}\right), 21.05\left(\mathrm{CH}_{2}\right), 21.00\left(\mathrm{CH}_{2}\right) ; \mathrm{MS} \mathrm{m} / z 264(\mathrm{M}+) ; 236$, $210,179,154,112,82,67,54,41$.
3-(2,5-Dioxopyrrolidin-1-yl)-piperidine-2,6-dione. (3): white solid yield $(0.10 \mathrm{~g}, 48 \%) .{ }^{1} \mathrm{H}$ NMR $\left(400 \mathrm{MHz}, \mathrm{DMSO}-d_{6}\right) \delta$ 11.0 (s, $1 \mathrm{H}, \mathrm{NH}), 4.9$ (dd, $1 \mathrm{H}, 12.5,5.5 \mathrm{~Hz}), 3.3$ (s, 1 H), 2.8 (m, $3 \mathrm{H}), 2.5(\mathrm{~m}, 1 \mathrm{H}), 2.4(\mathrm{~m}, 1 \mathrm{H}), 1.9(\mathrm{~m}, 1 \mathrm{H}) ; 13 \mathrm{C} \mathrm{NMR}$ (100 MHz, DMSO- $d_{6}$ ) 176.9, 172.7, 169.3, 49.0, 30.7, 28.0, 22.1; MS $m / z 210(\mathrm{M}+)$ 182, 167, 125, 112, 83, 68, 5641.

3-(2,6-Dioxopiperidin-3-yl)-3-aza-bicyclo[3.2.0]heptane-2,4dione. (4): a white solid (54\% yield). $1 \mathrm{H} \mathrm{NMR}(400 \mathrm{MHz}$, DMSO- $\left.d_{6}\right) \delta 11.06(\mathrm{~s}, 1 \mathrm{H}, \mathrm{NH}), 4.95(\mathrm{dd}, 1 \mathrm{H}, 12.5,5.5 \mathrm{~Hz})$, 2.84 (m, $2 \mathrm{H}), 2.52$ (m, $4 \mathrm{H}), 2.02$ (m, $2 \mathrm{H}), 1.92$ (m, $2 \mathrm{H})$; ${ }^{13} \mathrm{C}$ NMR (100 MHz, DMSO-d $\left.d_{6}\right) 179.0(\mathrm{C}=\mathrm{O}), 172.7(\mathrm{C}=\mathrm{O})$, $169.4(\mathrm{C}=\mathrm{O}), 48.7(\mathrm{CH}), 49.1(\mathrm{CH}), 37.9(\mathrm{CH}), 37.7\left(\mathrm{CH}_{2}\right)$, $30.7\left(\mathrm{CH}_{2}\right), 22.1\left(\mathrm{CH}_{2}\right), 22.0\left(\mathrm{CH}_{2}\right), 21.0\left(\mathrm{CH}_{2}\right) ; \mathrm{MS} m / z 236$ $(\mathrm{M}+)$ 208, 151, 106, 112, 96, 83, 55, 41.

(2,6-Dioxopiperidin-3-yl)-3a,4,7,7a-tetrahydro-1H-4,7-ethanoisoindole-1,3(2H)-dione. (5): a white solid (62\% yield). $1 \mathrm{H}$ NMR (400 MHz, DMSO-d6) $\delta 11.0(\mathrm{~s}, 1 \mathrm{H}, \mathrm{NH}), 6.1$ (m, 2 $\mathrm{H}), 4.8(\mathrm{dd}, 1 \mathrm{H}, 12.5,5.5 \mathrm{~Hz}), 3.0(\mathrm{~m}, 4 \mathrm{H}), 2.8(\mathrm{~m}, 1 \mathrm{H}), 2.5$ (m, $1 \mathrm{H}), 2.3(\mathrm{~m}, 1 \mathrm{H}), 1.7(\mathrm{~m}, 1 \mathrm{H}), 1.6(\mathrm{~d}, 2 \mathrm{H}, 7.5 \mathrm{~Hz}), 1.2(\mathrm{~d}$, $2 \mathrm{H}, 7.5 \mathrm{~Hz}) ; 13 \mathrm{C}\left(100 \mathrm{MHz}, \mathrm{DMSO}-d_{6}\right) \delta 177.75(\mathrm{C}=\mathrm{O}), 177.71$ $(\mathrm{C}=\mathrm{O}), 172.57(\mathrm{C}=\mathrm{O}), 168.73(\mathrm{C}=\mathrm{O}), 132.09(\mathrm{CH}), 131.82$ $(\mathrm{CH}), 48.75(\mathrm{CH}), 43.37(\mathrm{CH}), 31.39(\mathrm{CH}), 31.22(\mathrm{CH}), 30.48$ $(\mathrm{CH}), 29.79(\mathrm{CH}), 23.17\left(\mathrm{CH}_{2}\right), 22.98\left(\mathrm{CH}_{2}\right), 22.87\left(\mathrm{CH}_{2}\right)$, $21.29\left(\mathrm{CH}_{2}\right)$; MS m/z $288(\mathrm{M}+)$ 260, 209, 178, 149, 136, 112, 99, $80,78,54,41$.

\section{Disclosure}

The statements made herein are solely the responsibility of the authors.

\section{Competing Interests}

The authors declare that they have no competing interests.

\section{Acknowledgments}

Yousef M. Hijji would like to thank QNRF for support: NPRP award from Qatar National Research Fund (a member of The Qatar Foundation) [NPRP-.7-495-1-094]. Ellis Benjamin would like to thank the School of Natural Sciences and Mathematics at Stockton University.

\section{References}

[1] R. Talaat, W. El-Sayed, H. S. Agwa, A. M. Gamal-Eldeen, S. Moawia, and M. A. H. Zahran, "Anti-inflammatory effect of thalidomide dithiocarbamate and dithioate analogs," ChemicoBiological Interactions, vol. 238, pp. 74-81, 2015.

[2] M. Y. Kim, R. Sposto, A. Swaika et al., "Pharmacoeconomic implications of lenalidomide maintenance therapy in multiple myeloma," Oncology, vol. 87, no. 4, pp. 224-231, 2014.

[3] Y. Liu, X. Huang, X. He et al., "A novel effect of thalidomide and its analogs: suppression of cereblon ubiquitination enhances ubiquitin ligase function," The FASEB Journal, vol. 29, no. 12, pp. 4829-4839, 2015. 
[4] L. Roziaková, M. Mistrík, and A. Bátorová, "Pomalidomide in the treatment of relapsed and refractory multiple myeloma," Klinicka Onkologie, vol. 27, no. 5, pp. 318-325, 2014.

[5] G. Fouquet, C. Bories, S. Guidez et al., "Pomalidomide for multiple myeloma," Expert Review of Hematology, vol. 7, no. 6, pp. 719-731, 2014.

[6] C. Yang, P. Singh, H. Singh, M.-L. Le, and W. El-Matary, "Systematic review: thalidomide and thalidomide analogues for treatment of inflammatory bowel disease," Alimentary Pharmacology \& Therapeutics, vol. 41, no. 11, pp. 1079-1093, 2015.

[7] S. Harbour and N. Brown, "Thalidomide improves clinical remission in children with Crohn's disease," Archives of Disease in Childhood, vol. 100, no. 2, article 111, 2015.

[8] S. C. Ng, "Thalidomide and refractory crohn's disease: what is in the future?" Journal of Clinical Gastroenterology, vol. 48, no. 6, pp. 476-477, 2014.

[9] S. Kamath, S. A. Vaccaro, T. H. Rea, and M. T. Ochoa, "Recognizing and managing the immunologic reactions in leprosy," Journal of the American Academy of Dermatology, vol. 71, no. 4, pp. 795-803, 2014.

[10] S. Zhou, F. Wang, T.-C. Hsieh, J. M. Wu, and E. Wu, "Thalidomide-a notorious sedative to a wonder anticancer drug," Current Medicinal Chemistry, vol. 20, no. 33, pp. 41024108, 2013.

[11] C. Mahony, L. Erskine, J. Niven, N. H. Greig, W. D. Figg, and N. Vargesson, "Pomalidomide is nonteratogenic in chicken and zebrafish embryos and nonneurotoxic in vitro," Proceedings of the National Academy of Sciences of the United States of America, vol. 110, no. 31, pp. 12703-12708, 2013.

[12] M. Alsina, P. S. Becker, X. Zhong et al., "Lenalidomide maintenance for high-risk multiple myeloma after allogeneic hematopoietic cell transplantation," Biology of Blood and Marrow Transplantation, vol. 20, no. 8, pp. 1183-1189, 2014.

[13] L. St John, S. M. Gordon, R. Childs et al., “Topical thalidomide gel in oral chronic GVHD and role of in situ cytokine expression in monitoring biological activity," Bone Marrow Transplantation, vol. 48, no. 4, pp. 610-611, 2013.

[14] P. J. Martin, Y. Inamoto, P. A. Carpenter, S. J. Lee, and M. E. D. Flowers, "Treatment of chronic graft-versus-host disease: past, present and future," Korean Journal of Hematology, vol. 46, no. 3, pp. 153-163, 2011.

[15] L. Song, X. Zhou, and X. Li, "Phase II trial of granulocytemacrophage colony-stimulating factor plus thalidomide in older patients with castration-resistant prostate cancer," Molecular and Clinical Oncology, vol. 3, no. 4, pp. 865-868, 2015.

[16] Z. Qiao, J. Yuan, J. Shen et al., "Effect of thalidomide in combination with gemcitabine on human pancreatic carcinoma SW1990 cell lines in vitro and in vivo," Oncology Letters, vol. 9, no. 5, pp. 2353-2360, 2015.

[17] P. M. Da Costa, M. P. Da Costa, A. A. Carvalho et al., "Improvement of in vivo anticancer and antiangiogenic potential of thalidomide derivatives," Chemico-Biological Interactions, vol. 239, article no. 7412, pp. 174-183, 2015.

[18] L. C. D. Coêlho, M. V. De Oliveira Cardoso, D. R. M. Moreira et al., "Novel phthalimide derivatives with TNF- $\alpha$ and IL$1 \beta$ expression inhibitory and apoptotic inducing properties," MedChemComm, vol. 5, no. 6, pp. 758-765, 2014.

[19] M. V. De Oliveira Cardoso, D. R. Magalhães Moreira, G. B. Oliveira Filho et al., "Design, synthesis and structure-activity relationship of phthalimides endowed with dual antiproliferative and immunomodulatory activities," European Journal of Medicinal Chemistry, vol. 96, pp. 491-503, 2015.

[20] A. Diamanti, T. Capriati, B. Papadatou et al., "The clinical implications of thalidomide in inflammatory bowel diseases," Expert Review of Clinical Immunology, vol. 11, no. 6, pp. 699708, 2015.

[21] Y. Huang, Y. Zang, L. Zhou, W. Gui, X. Liu, and Y. Zhong, "The role of TNF- $\alpha / \mathrm{NF}-\kappa \mathrm{B}$ pathway on the up-regulation of voltage-gated sodium channel Nav1.7 in DRG neurons of rats with diabetic neuropathy," Neurochemistry International, vol. 75, pp. 112-119, 2014.

[22] M. S. Ali, R. M. Starke, P. M. Jabbour et al., "TNF- $\alpha$ induces phenotypic modulation in cerebral vascular smooth muscle cells: implications for cerebral aneurysm pathology," Journal of Cerebral Blood Flow and Metabolism, vol. 33, no. 10, pp. 15641573, 2013.

[23] A. Vangsted, T. W. Klausen, and U. Vogel, "Genetic variations in multiple myeloma II: association with effect of treatment," European Journal of Haematology, vol. 88, no. 2, pp. 93-117, 2012.

[24] L. Mazzoccoli, S. H. Cadoso, G. W. Amarante et al., "Novel thalidomide analogues from diamines inhibit proinflammatory cytokine production and CD80 expression while enhancing IL-10," Biomedicine \& Pharmacotherapy, vol. 66, no. 5, pp. 323-329, 2012.

[25] M. Çizmecioğlu, V. Pabuççuoğlu, P. Ballar, A. Pabuççuoğlu, and Z. Soyer, "Synthesis and screening of cyclooxygenase inhibitory activity of some 1,3-dioxoisoindoline derivatives," ArzneimittelForschung/Drug Research, vol. 61, no. 3, pp. 186-190, 2011.

[26] G. D. Ferguson, K. Jensen-Pergakes, C. Wilkey et al., "Immunomodulatory drug CC-4047 is a cell-type and stimulus-selective transcriptional inhibitor of cyclooxygenase 2," Journal of Clinical Immunology, vol. 27, no. 2, pp. 210-220, 2007.

[27] J. L. Masferrer, "Methods of using a combination of cyclooxygenase-2 selective inhibitors and thalidomide for the treatment of neoplasia," US20030013739A1, 2003.

[28] E. D. Q. Crusoe, F. Higashi, M. P. N. C. Padilha et al., "Outcomes of autologous transplantation for multiple myeloma according to different induction regimens," Revista Brasileira de Hematologia e Hemoterapia, vol. 36, no. 1, pp. 19-24, 2014.

[29] M. Bolzoni, P. Storti, S. Bonomini et al., "Immunomodulatory drugs lenalidomide and pomalidomide inhibit multiple myeloma-induced osteoclast formation and the RANKL/OPG ratio in the myeloma microenvironment targeting the expression of adhesion molecules," Experimental Hematology, vol. 41, no. 4, pp. 387.e1-397.e1, 2013.

[30] M. Lazarini, F. Traina, S. M. Winnischofer, F. F. Costa, M. L. S. Queiroz, and S. T. O. Saad, "Effects of thalidomide on longterm bone marrow cultures from patients with myelodysplastic syndromes: induction of IL-10 expression in the stromal layers," Leukemia Research, vol. 35, no. 8, pp. 1102-1107, 2011.

[31] E. Shannon, R. Noveck, F. Sandoval, and B. Kamath, "Thalidomide suppressed IL- $1 \beta$ while enhancing TNF- $\alpha$ and IL-10, when cells in whole blood were stimulated with lipopolysaccharide," Immunopharmacology and Immunotoxicology, vol. 30, no. 3, pp. 447-457, 2008.

[32] J. Chen, K. Natte, A. Spannenberg, H. Neumann, M. Beller, and $\mathrm{X}$.-F. Wu, "Efficient palladium-catalyzed double carbonylation of $o$-dibromobenzenes: synthesis of thalidomide," Organic and Biomolecular Chemistry, vol. 12, no. 30, pp. 5578-5581, 2014. 
[33] Z. Xiao, K. Schaefer, S. Firestine, and P.-K. Li, "Solid-phase synthesis of thalidomide and its analogues," Journal of Combinatorial Chemistry, vol. 4, no. 2, pp. 149-153, 2002.

[34] B. Satyanarayana, P. Murali Krishna, and D. Ramachndran, "A novel and efficient synthesis of thalidomide," International Journal of ChemTech Research, vol. 3, no. 1, pp. 234-237, 2011.

[35] N. Shibata, T. Yamamoto, and T. Toru, "Synthesis of 2(2, 6-dioxo-3-piperidinyl)-1h-isoindole-1,3(2h)-dione (thalidomide)," in Topics in Heterocyclic Chemistry, vol. 8, pp. 73-97, Springer, Berlin, Germany, 2007.

[36] X.-H. Yuan, H.-Q. Guo, X.-P. Qiu, C.-Q. Kang, X.-D. Liu, and L.-X. Gao, "One-step synthesis of thalidomide and its important derivatives," Chemical Journal of Chinese Universities, vol. 26, no. 8, pp. 1477-1479, 2005.

[37] M.-Y. Chang, C.-H. Chang, S.-T. Chen, and N.-C. Chang, "A synthesis of thalidomide," Journal of the Chinese Chemical Society, vol. 49, no. 3, pp. 383-385, 2002.

[38] G. W. Muller, W. E. Konnecke, A. M. Smith, and V. D. Khetani, "A concise two-step synthesis of thalidomide," Organic Process Research \& Development, vol. 3, no. 2, pp. 139-140, 1999.

[39] F. A. Luzzio, D. Y. Duveau, and W. D. Figg, "A chiral pool approach toward the synthesis of thalidomide metabolites," Heterocycles, vol. 70, pp. 321-334, 2006.

[40] H. B. Casazza Fanchini and A. Rodriguez Welton, "Novel process for the synthesis of thalidomide," MX2006008774A, 2008.

[41] M. Alpegiani, A. Mazzoni, D. Vergani, and W. Cabri, "Process for the one-pot synthesis of thalidomide directly from glutamine using phthaloylating agents and condensing agents," EP1602654A1, 2005.

[42] R. Varala and S. R. Adapa, "A practical and efficient synthesis of thalidomide via $\mathrm{Na}$ /liquid $\mathrm{NH}_{3}$ methodology," Organic Process Research and Development, vol. 9, no. 6, pp. 853-856, 2005.

[43] N. Flaih, C. Pham-Huy, and H. Galons, "An expeditious synthesis of cyclic imides. Tetrahedron Lett. Tetrahedron," Asymmetry, vol. 6, pp. 3697-3698, 1999.

[44] J. A. Seijas, M. P. Vazquez-Tato, C. Gonzalez-Bande, M. M. Martinez, and B. Pacios-Lopez, "Microwave promoted synthesis of a rehabilitated drug: thalidomide," Synthesis, vol. 2001, no. 7, pp. 999-1000, 2001.

[45] S. You, Y. Li, D. Chen et al., "Application of microwaveassisted method in synthesis of thalidomide," Huaxue Yanjiu Yu Yingyong, vol. 23, pp. 652-656, 2011.

[46] J. Guo, Y. Zheng, D. Guo et al., "Application of the microwaveassisted method in synthesis of thalidomide amino acid derivatives," Huaxue Yanjiu Yu Yingyong, vol. 21, pp. 582-586, 2009.

[47] Y. M. Hijji and E. Benjamin, "Efficient microwave assisted syntheses of unsubstituted cyclic imides," Heterocycles, vol. 68, no. 11, pp. 2259-2267, 2006.

[48] E. Benjamin and Y. Hijji, "The synthesis of unsubstituted cyclic imides using hydroxylamine under microwave irradiation," Molecules, vol. 13, no. 1, pp. 157-169, 2008.

[49] Y. M. Hijji, E. Benjamin, E. Benjamin,R. J. Butcher, and J. P. Jasinski, "3-(2,6-dioxopiperidin-3-yl)-3-aza-bicyclo[3.2.0]hep- tane-2,4-dione," Acta Crystallographica, vol. 65, pp. 394-395, 2009. 

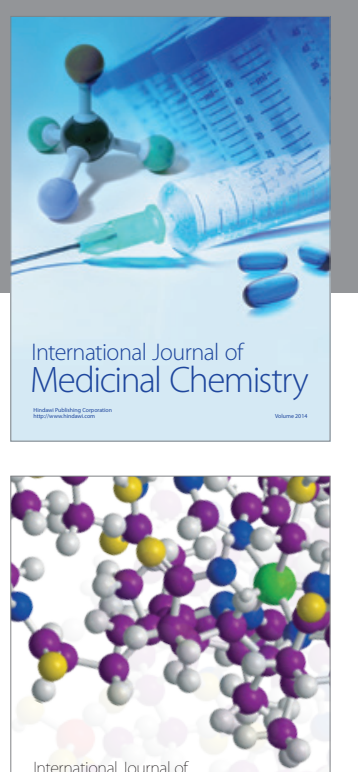

Carbohydrate Chemistry

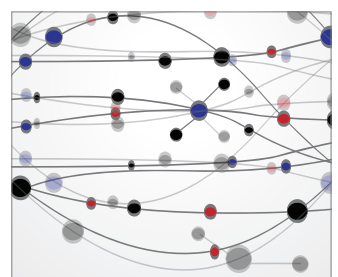

The Scientific World Journal
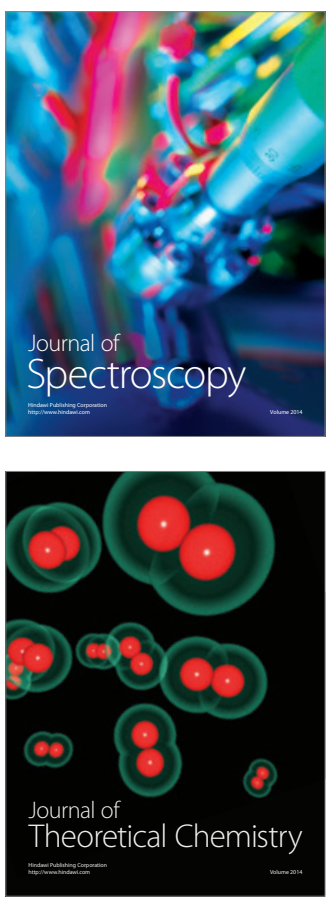
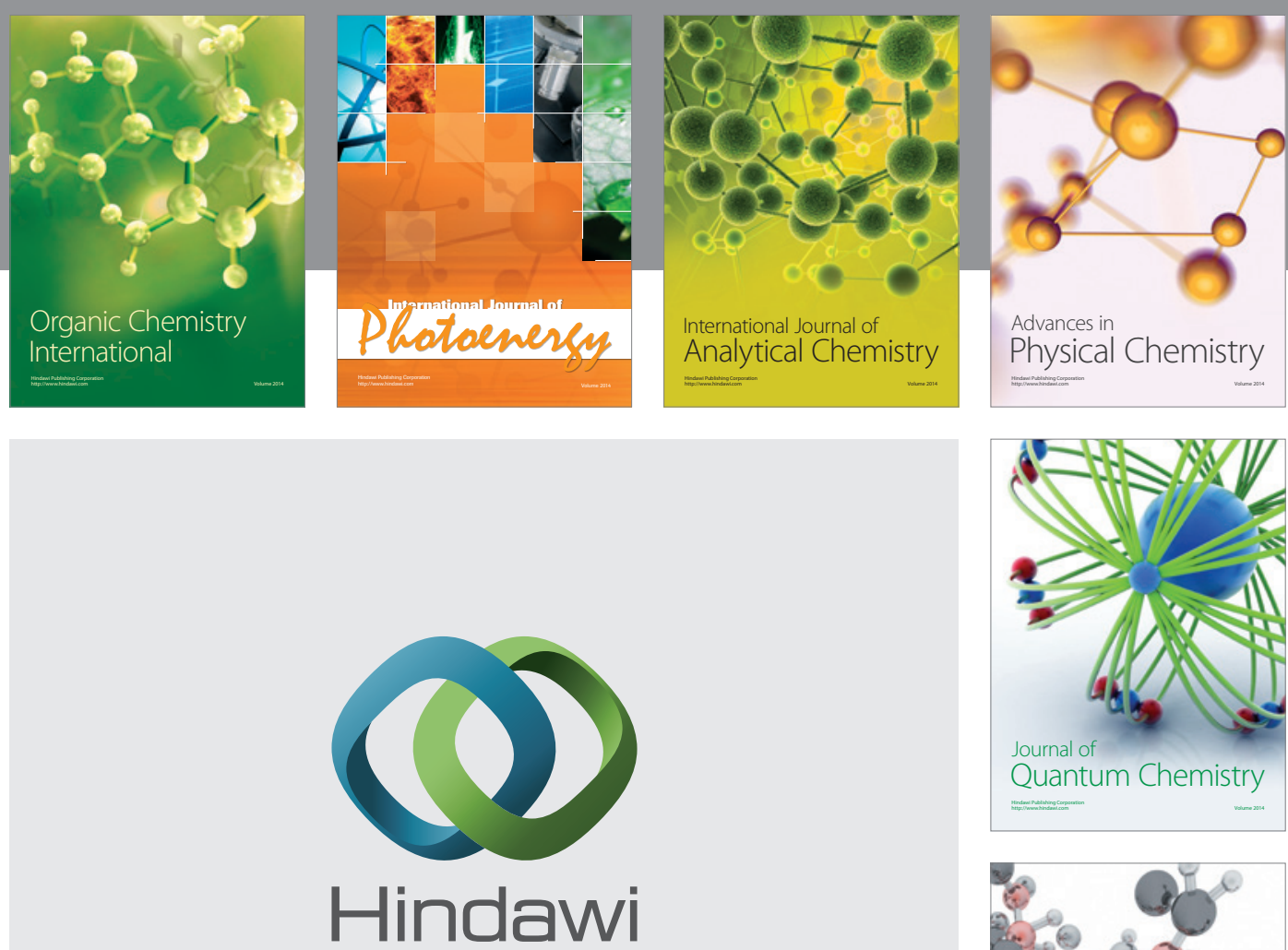

Submit your manuscripts at

https://www.hindawi.com

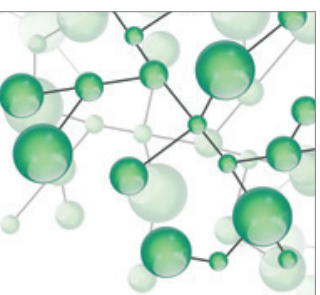

International Journal of

Inorganic Chemistry
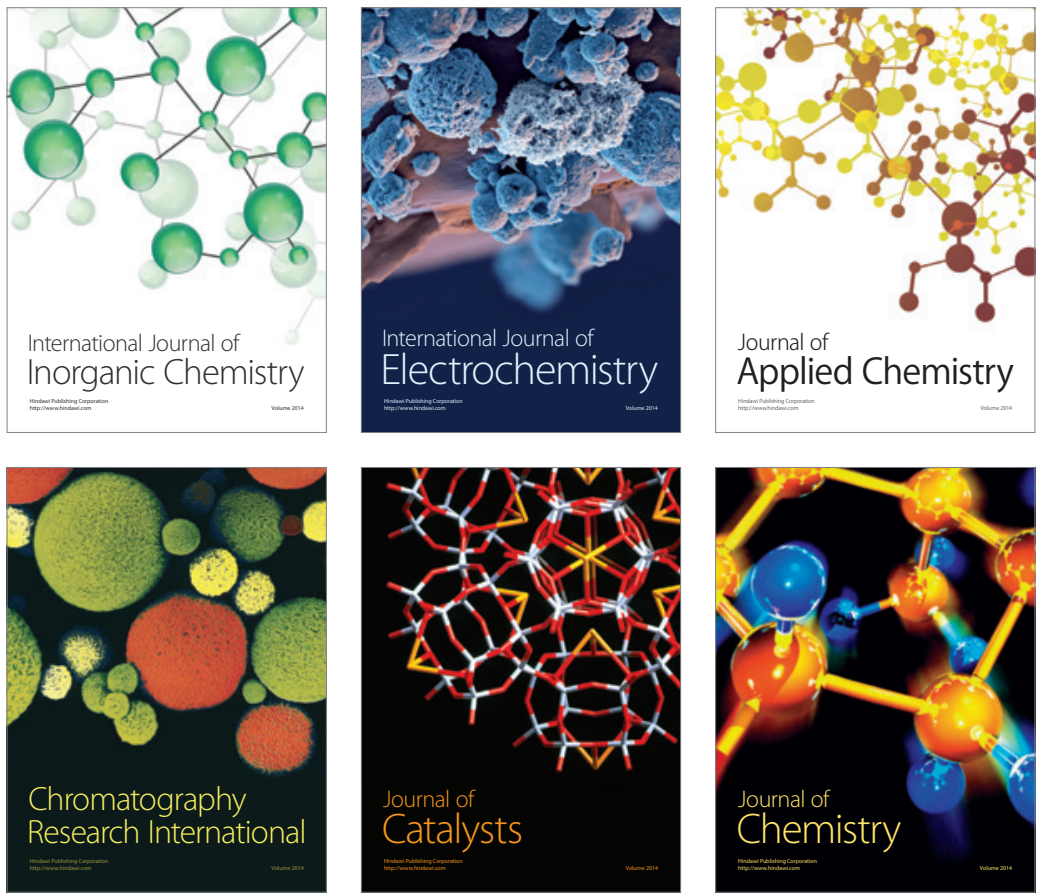

Journal of

Applied Chemistry
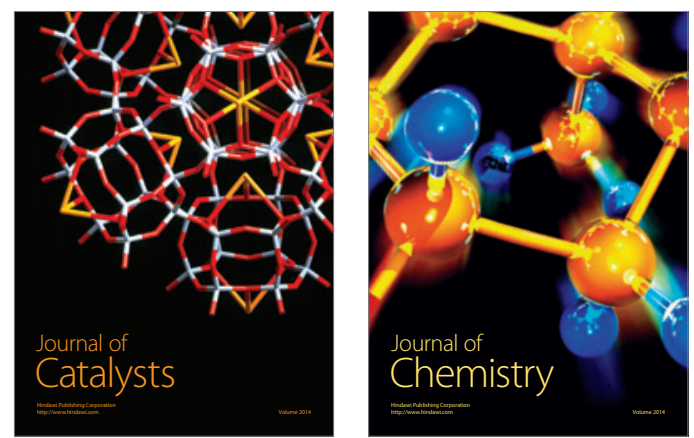
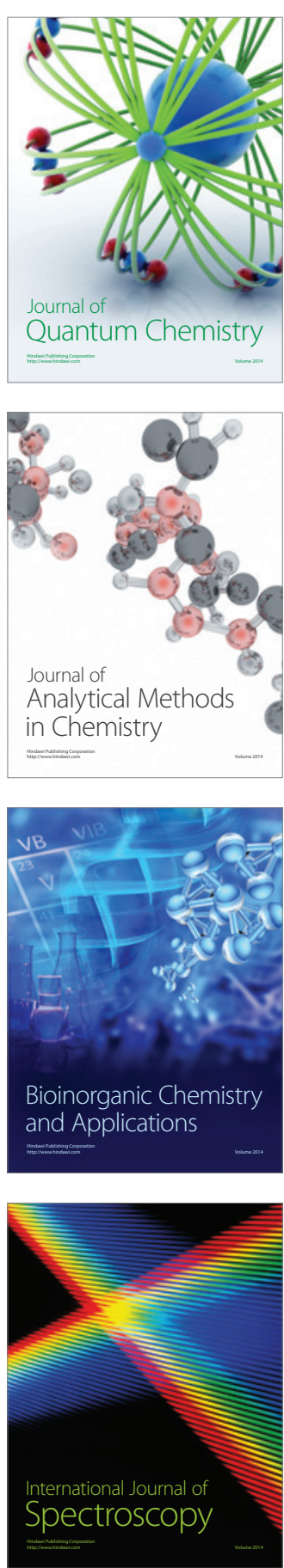